\title{
RNA Polymerase II
}

National Cancer Institute

\section{Source}

National Cancer Institute. RNA Polymerase II. NCI Thesaurus. Code C95948.

An enzyme complex that catalyzes the transcription of DNA to produce the precursor of messenger RNA and most small nuclear RNA and microRNA transcripts. 